Marketing and Branding Research

WWW.CIKD.CA

\title{
Contribution of Sectorial Brands to the Competitiveness of the Regions and the Emerging Brands
}

\author{
Ariana Daniela Del Pino Espinoza ${ }^{1 *}$, Freddy Ronald Veloz de la Torre ${ }^{2}$ \\ ${ }^{1,2}$ Escuela Superior Politécnica del Litoral, Guayaquil, Ecuador
}

Keywords:

Nation Brand, Global Brand, Territory Brand, Product Brand, City Brand

\section{Received}

13 May 2020

Received in revised form

14 May 2020

Accepted

14 June 2020

\begin{abstract}
Growing trends have generated new terms in brand quality and new brand categories. Global brands have encouraged the penetration of products in markets, but new contexts have emerged, where brands add value to the productive sectors and promote the creation and growth of new companies and new economies. An approach and analysis of the contemporary construction of the sector brand and the value it provides to insert countries, sector, territories, cities, regions and products in global markets was carried out. Because of this, a decomposition was made from macro to micro at all levels and how they have emerged with trends. On the other hand, in the Latin American context, we can observe the emergence of emerging brands that have their origin in the need to meet the demand of priority sectors or undertakings derived from the identification of unattended market niches, with the potential to become trademarks in a higher level. And ultimately, the emerging brand for new product, new trends and new sector focused in the younger consumer and the buyer experience from the emotional side. This research is a contribution to reading with a different perspective than that of the authors, which covers all the new levels of brands and how they are linked to the productive sectors.
\end{abstract}

The etymology of the word BRAND comes from the old Norwegian word BRANDR, which means to burn, as a representative symbol through the marking of fire, with the purpose of distinguishing one cattle from another through the brand; in classical Rome, potters marked the vases to be linked to the quality of the object, a practice that can be associated with exoteric and esoteric words, which represents the exterior or the visible for all, what we see of the brand, and the interior as the hidden, what we understand or transmit, respectively (Keller, 2005). 
The brand is "a name and / or signal whose purpose is to identify the product of a vendor or group of sellers, to differentiate it from rival products" (Stanton, Etzel, \& Walker, 2000, p. 264). Therefore, the brand sector or sectoral brand is a group of products of a specific sector of a country; For example, we can say Fruit of Chile (it brings together several products), relating certain standards (quality, taste, price, etc.) with the origin.

Lazo (2006) makes a reference of the sectoral brand in the aspect of its positioning, where it indicates that the brand works based on "comparative advantage" and "competitive advantage", from an initial perspective of production to international distribution. Lazo (2006) also associates the sectoral brand with "the existence of a territorial concentration", which is related to the grouping of a product or a sector (p. 37). These brands also have the impact of projection and perception; according to Crompton (1979) and Kotler, Haider and Rein (1994), the image is the sum of beliefs, ideas and impressions, so that the image of a country or a product allows a mental and social construction.

The sector brand is linked to the association of entrepreneurs or business and producers in the same sector, with the support of the country brand that functions as an umbrella brand. Every sectoral brand represents to each sector with its distinctive sign, it is difficult for the country (Del Pino \& Acevedo, 2019) According to Aravena and Mardones (2009) "they are brands that have a set of conceptual and graphic attributes that lead the positioning of a certain productive sector abroad" (p. 43).

The region brand is the brand designated by regions of countries or regions of production, the basis of city-marketing, which shows the values of a product-destination and positions the territorial identity through its brand, for example, the Coffee Cultural Landscape. The region brand supports the economic activity in all the sector, another example is the tourism that help to increase the imagen perception of a country (Bruwer \& Lesschaeve, 2012).

The information available on the creation process and methodologies for the implementation of sectoral brands is limited and, in some cases, restricted. The methodology used corresponds to theoretical works, and a review of the literature related to the brands will be carried out, from the macro aspect in the global sense, and then the contemporary construction of the micro of the sector or sectoral brand will be addressed. This article incorporates some of the concepts referred to brands of: country, territory, city, trade, sector, product and its link with the competitiveness of the regions, based on the bibliographic review, the critical and interpretative analysis of the most relevant contents in different aspects.

Lazo (2006) makes a huge contribution for the levels of the position of the brands, and with previous investigations of the authors, we have proceeded to delimit the levels based on the position of the brands to make a contribution and increase new levels as presented in Figure 1 (p. 37): 


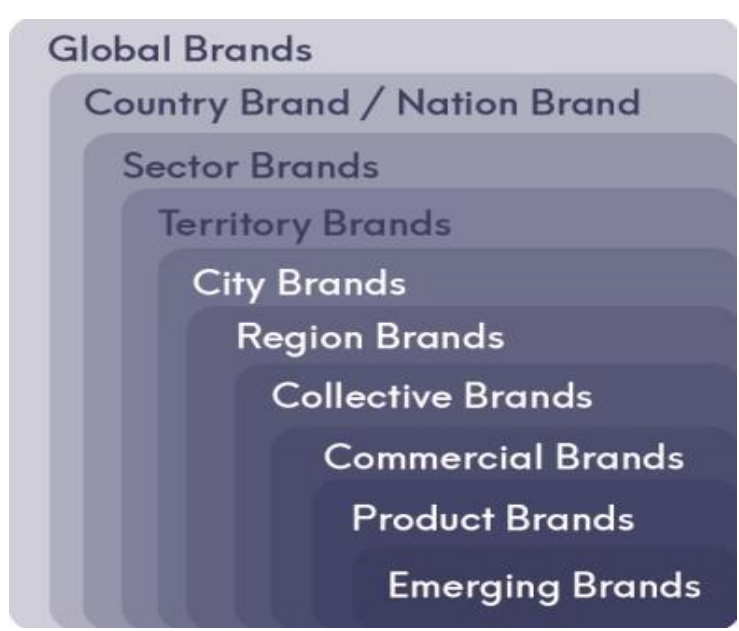

Figure 1. Brand position

Font: Based on Lazo (2006, p.37)

The levels of the Brands Position include (see Figure 1):

1. Global Brand: Brands that are exhibited and recognized in all countries without having a notorious origin. For example, Nike may be of United States but is globally recognized and does not refer to the country as Nike of the United States.

2. Country Brand: The country's name, which is currently distinctive for its sign or brand, is linked to the commercial part. For example, Chile Country and the Chilean wines.

3. Sector Brand: Representation of an association or group of the same product from the same country or group of several companies of the same product. For example, Wines of Chile or Juan Valdez Coffee (Colombian Coffee Growers Association).

4. Territory Brand: This brand is related to a territory of a country that may be a province or capital, but it focuses on the product. For example, the Eiffel Tower in Paris in France.

5. City Brand: As indicated, it gives relevance to the city of a country, for example, Salta in Argentina, New York in the United States.

6. Region Brand: It is linked to a smaller portion of a city. For example, Salcedo Ice Creams from Ecuador, related to San Miguel de Salcedo which is the capital of the canton Salcedo located in the province of Cotopaxi.

7. Collective Brand: Brands or companies that have a common name and are managed under the same firm. For example, Cheese (Camembert, Parmesan, Brie, Gouda, Stilton, Roquefort, Feta and others).

8. Commercial Brand: They are brands of commercial products that can be related to any type of product. For example, Dove.

9. Product Brand: Products from a country that may be from a small, medium or large company, for example, Inca Cola from Peru and trying to become a global brand with the name the Golden Kola.

10. Emerging Brand: They are young and innovative brands, emerging as Startup. For example, fintech Ripio in Argentina.

\section{Decomposition of the Global Brand to the Country Brand: The construction process}

Is it important to have all these levels and differentiating aspects within the world? The global brand can be perceived differently by each culture, which allows some products to distinguish themselves from others (Hernani, 2008, p. 44-45). As can be seen in Figure 1, the global brand functions as an 
umbrella brand of all the others until it reaches the emerging brand (new context). The role of brands is to present a differentiating concept that satisfies the needs of consumers and enhances a positive image of a country's identity, contributing to the improvement of competitiveness and its positioning in global markets, which is a goal for modern states.

The term Nation Brand or Country Brand was employed academically by Simon Anholt in 1998; the Country Brand of the 21st century is not entirely defined by the author, who refers to the term by means of cases and examples, indicating that the majority of successful brands really come from countries that in turn are a brand. In this sense, the association of the brand of a product given to a nation certainly has a positive image and generates mutually reinforcing relationships.

Anholt (1998) believes that "At its simplest level, this association between commercial and national brand is merely a case of positive associations with national products: a country is famous for producing certain items, and brands in related product categories benefit by association" ( $\mathrm{p}$. 396). According to Olins (2005) the nation brand began with the French revolution, who started it in a huge way, with internal identity.

It is meaningful to building a positive image for the country; based on identity attributes that gives value to products and services in a global context, is a state policy in many countries, with specific rules and goals established by agreements and public-private partnerships. This idea is driven by the new commercial relationships and policies that are established precisely through globalization. The country brand concept, therefore, gains strength as an indicator of positioning that contributes to the competitiveness of countries, and becomes part of government programs, transcending ideological or political differences. At the brand and country image observation, Echeverri indicates that:

"the image of a country is the perception that direct, indirect, real and potential countries consumers have; and it is equivalent to the sum of all the elements that make up the country, plus those that are generated to communicate its characteristics; these perceptions contain differentiating connotations. All countries are different, that is how they share common elements" (Echeverri Cañas, 2015).

In this scenario, the products, in addition to the intrinsic quality that they must have, must also be capable of providing significant experiences based on the production traditions that link the product with the country of origin. Before addressing this, we must point out that culture can be defined as "the collective programming of the mind that distinguishes the members of one category or group of people from another" (Hofstede, 1999, p.34). The collective brands "share a common brand name" inside an autonomous firm, also can share the region, country, designation of origin and geographical indication (Fishman, Finkelstein, Simhon, \& Yacouel, 2017, p.1)

It is considerable, therefore, that the country becomes an adjective of the products, and that the products build their own associations as a nation's culture of making. This means moving from a "Made in" product to a "Made by" product. In other words, it means designing, in a systemic way, the attributes and relationships that allowed us to pass, for example, from Chocolate of Swiss to Swiss chocolate, from Wine of Chilean to Chilean wine, from Cocoa of Ecuador, to Ecuadorian cocoa, this is a main point, the name of the country is the reinforcement to the product. This approach makes the Product Nation or Product Country relationship an attribute reference that acts as a syllogism for other products brands from the same country.

Fan (2006) explains that country is an area of land occupied by a group of people who constitute the nation, and manifests two concepts: nation branding and nation brand; the branding focuses on 
marketing techniques and promotion of the image of a national space (p.5) "The really innovative thing is to baptize it with the name of nation branding" (de San Eugenio Vela, 2012, p. 152). Therefore, Country Brand refers to the country, but not to the concept of nation. Similarly, the country brand precept that includes a graphic representation are attributes of association to the place by some unique concept. Thus, some products have a strong relation with the country and the nation, and in this moment is where the sector brand intervenes.

\section{Developing Trademark Approach: Commercial Brand for Sectoral Brand}

A Commercial brand is linked to the doctrines of industrial property, manufacturing and geographical indications (Schmitz Vaccaro, 2012, p. 11), but over time the demand for "products in all sectors" has increased (Trout, 2001, p. 2). It can be linked to a place or be a global factor that graphically represents a specific product or service.

According to Morales (2010), the trademark "is a legal institution that associates a sign with specific products or services and whose purpose is to distinguish the latter from other analogs in the market, which in its definition already warns of its use vocation. In this sense, a brand that is not used does not fulfill its own function and may end up being a subterfuge of paper destined to hinder commercial competition" (Morales, 2010). Therefore, the conglomerates of determined products contribute to the development of a productive sector; from the point of view of the sector or sectoral brand, the associativity would be the motor to potentiate the productive development of a nation. We can associate the commercial brand or the trademark with the product-company brand that, according to Lazo (2006), is at the first level of international market positioning, where the products that are exported are differentiated and adapted to international requirements (p. 36), these attributes being typical of the sector brand.

A commercial brand that is from a region or an area of a country can be transformed into a sectoral brand with the right properties and the right associativity of producers to respond to a global demand, with the support of the nation and adequate state policies. It even helps the productive and economic development of the country. It is clear that the sector or sectoral brand aims to expose the important points of a region or of the whole country, with particular attributes and characteristics, such as the geographical space that externalizes a productive export potential for an economic growth of a specific public. One point to be taken into account is the number of companies of different sizes around these particular sectors, which commercialize their trademarks or commercial brand autonomously, while through a sectoral brand, there are some specific features like the inclusion, grouping or association of small, medium and large companies linked to the same product/sector.

\section{Contribution from the Sectoral Brand to the Country Brand and Territory Brand}

The territory brand, also known as brand place (Alameda \& Fernández, 2012, p. 1), has the particularity of bringing together the differential attributes of a space, with an added value (Monerris, 2008), which is a unifying element referring to the geographical aspect, to obtain a certain positioning (López-Lita \& Benlloch, 2005, 2006), based on a strategy whose main objective is the increase of tourism, regional or national (de San Eugenio Vela 2012, p. 148); the territory brand is not the same as the country brand, nor the city brand, since a territory brand could only refer to a single tourist place. If a territory possesses a single product from a fruitful sector, it contributes directly to a double diffusion, not only for the country but also for the territory in 
particular, which translates into an increase in tourism potential, and acquisition of that potential product, generating a double economic flow.

The territory brand can support a sectoral brand, position, and relate a product to its place of origin, which contributes to the recognition of the territory associated with a product, tangible or intangible. Examples such as "empanadas salteñas" from Salta in Argentina, "deep dish pizza" from Chicago in the United States, "cocido madrileño" from Madrid, "taquitos al pastor" from Mexico, "mate" from Argentina or "calimocho" (Kalimotxo) from San Sebastián in Spain can be the origin of new sectoral brands, for their realization, place of origin or product differentiation. Likewise, the link of a trademark or the commercial brand with a specific country, for example, Juan Valdez Coffee from Colombia, which is also a clear example of the association of a product with a country and has origin product, allows us to infer that this type of associations can also, with an appropriate strategy, lead to the creation of sectoral brands. "In 1959, the Colombian Coffee Growers Federation created Juan Valdez ${ }^{\circledR}$, a fictional character who represents Colombian coffee growers and their traditions." (Juan Valdez, 2020). Like Sherfey said "the organization is now a global retail operation" (Sherfey, 2015), this is a perfect example of Sectoral brand.

\section{A powerful weapon for countries the Sectoral Brands}

The newspaper El Comercio del Perú (2015) exposed through an article the power of a sectoral brand and how it can become a sign of productive differentiation, analyzing how Chile has managed to increase its participation in global markets in less than five years, using positioning strategies powered by sectoral brands. Anholt (2007) states that the effect of the country of origin is powerful and complex, therefore, sectoral brands to promote a product from the economic point of view generate a systemic change that allows the improvement of the visibility of products, promoting exports. Chile, which is a case of interest in Latin America, has generated a change in the management of the products that it offers to the world markets.

At this point it is important to point out that the sectoral brand gathers a conglomerate of perspectives, and its success is directly related to the strength of the public-private alliance that supports it. Nation products or origin products are certificates products of some region (van der Lans, van Ittersum, De Cicco, \& Loseby, 2001), this product has designation of origin (PDO) of their country, for example Fine Aroma Cacao from Ecuador (Quintana Lombeida \& Aguilar, 2018). García (2001) indicates that the "product is what the advertiser factory or distributes and, ultimately, what it offers to consumers. Brand is what consumers buy; it goes beyond the materiality of the product itself' (p. 71). The sectoral brand has two very important properties, as they are: distinguish and differentiate.

According to the Merriam Webster, distinguishing is "2. tr. Make something different from something else by means of some particularity, signal, currency" (Real Academia Española, 2018) and differentiate is " 1 . tr. Make distinction, know the diversity of things" (Real Academia Española, 2018). Within Figure 1, where the position of the brands is shown through a hierarchical structure, the sector brand is under the country brand.

The evidence shows that the sector brand contributes to the improvement of the penetration of products in world markets, positively impacts the reputation of countries, fosters cooperation in a fair competition environment with clear rules, promotes economic growth, encourages to small and medium enterprises to incorporate good manufacturing practices, waste management, new technologies and social responsibility policies, in addition to adding value to products and contributing to satisfying the demand for products or services in various segments of the population. 


\section{Projection of the Emerging brands in Latin America}

Emerging brands are also known as Breakthrough Brands or Clean Slate Brands. According to Merca 2.0 "emerging brands are those that have no past. That is, they are new, better, open and receptive." Due to the generational changes of consumers, they show greater willingness to consume new products and accept new brands. In this context, in Brazil, cataloged as an emerging market and also as a Latin American benchmark, the level of consumer confidence in emerging brands reaches $65 \%$ (Gonzalez, 2015).

According to Russ Rubino, VP of Marketing at Intercontinental Exchange, "These nextgeneration brands represent the future. They are disruptive and defining, innovative and impactful", that will change the world, driving to change and realizing economic growth. "These young companies exemplify the New York Stock Exchange's mission in many ways: to help big companies do great things by improving the lives of people and society with integrity, vision, humanity and impact." (Mercado, 2017).

Most emerging brands have their origins in ventures and the emergence of new markets and new trends, established based on new experiences for consumers, and promoted largely by the so-called influencers; They seek to differentiate themselves from traditional brands and offer new shopping experiences or products. According to a report presented by the consultancy ComScore, "Latin America is the region most involved in social networks globally" (Marchant \& Castro, 2017).

Emerging brands can be, in terms of their time of existence, seasonal or temporary brands, which they sell through social networks, conquering the centennial or $\mathrm{Z}$ generation, who seek options beyond the scope of traditional brands, with emphasis in the products and the properties or attributes that distinguish them from others. Could these brands arise from a new demand of productive sectors and become sectoral brands? The change in the preferences of new users is evident and imminent.

\section{Implication of the Study and Future Research Recommendation}

This research that has been developed from a previous conception of a model for the implementation of sectoral brands. It has been incorporating new resources that are valuable for the countries and the productive sectors. For future research, the relationship between the sector brand and the social imaginary is studied from the point of view of the anthropology study and its possible implications.

\section{Conclusions}

The sectoral brands, in their various fields of application, present several difficult adoption challenges to the states, regions, cities, industries, entities and people involved in the development, manufacture and marketing of products. The political, economic, and legal implications that go hand in hand with the implementation of a sectoral brand require a firm commitment that transcends the limits of a company.

How to compete and cooperate at the same time, how to resolve differences without affecting the achieved objectives and the achievement of common goals are issues to be addressed and resolved before outlining the first aspects of the sectoral brand design. In this sense, be aware that agreements imply a change in old practices, accept a set of rules, foster an environment of trust among competitors, share information and collaborate to achieve the level of expected quality that is essential. 
If we take as reference, the Chilean experience once again, we observe that the state plays a fundamental role in the creation and promotion of sectoral brands through ProChile, an entity attached to the Ministry of Foreign Affairs of that country. It is enough to have a first look at its website to clearly observe its objectives: to train producers of exportable products, to promote the exportable offer of Chilean products to world markets, and to link potential buyers with Chilean exporters able to satisfy their demand, with emphasis on food, industries and services.

According to the Central Bank of Chile, exports from January to September of 2018 totaled 57.651 USD million, $16.5 \%$ more in relation to the same period of the previous year. This positive trend has been maintained in recent years and resulted in the effectiveness of the sectoral brands. Regarding the analysis and figures presented in relation to emerging brands, it is logical to point out that these may arise from a single sector of a region or territory, and have the potential to become sectoral brands, as well as be linked to promote; in addition to the consumption of products and tourism.

\section{References}

Alameda, D., \& Fernández, E. (2012). La comunicación de las marcas territorio [Territory brand communication]. Revista Latina de Comunicación Social, 1-28.

Anholt, S. (1998). Nation-Brand of the twenty-first century. Journal of Brand Management, 5(6), 395-406.

Anholt, S. (2007). Competitive identity: The new brand management for nations, cities and regions. Nueva York: Palgrave Macmillan.

Aravena, P., \& Mardones, M. (2009). Thesis Development of Sector brands and their impact on the Country Brand: Chile. (Tesis Desarrollo de marcas Sectoriales y su impacto en su Imagen País: Chile). Santiago: Universidad de Chile.

Bruwer, J., \& Lesschaeve, I. (2012). Wine tourists' destination region brand image perception and antecedents: conceptualization Conceptualization of a winescape framework. Journal of Travel \& Tourism Marketing, 29(7), 611-628. https://doi.org/10.1080/10548408.2012.719819

Crompton, J. (1979). An assessment of the image of Mexico as a vacation destination and the influence of geographical location upon the image. Journal of Travel Research, 17(4), 18-23.

de San Eugenio Vela, J. (2012). From nation state to brand state: The Role of public diplomacy and country branding in the new stage of the international relations. Revista de Estudios Sociales, 145-157.

Del Pino, A., \& Acevedo, O. (2019). Model for the implementation of sectoral brands: Proposal for methodological development. Iberian Journal of Information Systems and Technologies - RISTI, E20, 49-62.

Echeverri Cañas, L. M. (2015, Junio). What is a country brand? (¿Qué es Marca País?). Retrieved from Pais Marca OBS: https://paismarca.com/que-es-marca-pais-2/

El Comercio. (2015, January 18). El poder de una marca sectorial. La efectividad del signo distintivo de un rubro productivo [The power of sector brand. The effectiveness of the distinctive sign of a productive item]. Retrieved from El Comercio: https://search.proquest.com/docview/1646275973?accountid=171402

Fan, Y. (2006). Branding the nation: What is being branded? Journal of Vacation Marketing, 12(1), 5-14.

Fishman, A. \&., \& Yacouel, N. (2018). Collective brands. International Journal of Industrial Organization, 59(C), 316-339.

García Uceda, M. (2001). Las Claves de la Publicidad, 5a edITION [Keys to advertising]. Madrid: Esic Editorial.

Gonzalez, V. (2015, September 09). Marketing (Mercadotecnia). Retrieved from Meca 2.0: https://www.merca20.com/que-esuna-marca-emergente/

Hernani, M. (2008). Percepción de la personalidad de una marca global y de valores: Un estudio comparativo entre consumidores brasileños y peruanos [Perception of the personality of a global brand and of values: a comparative study between Brazilian and Peruvian consumers]. Contabilidad y Negocios, 3(5), 44-54.

Hofstede, G. (1999). Culturas y organizaciones: El software mental [Cultures and organizations: Mental software]. P. Madrid: Alianza Editorial.

Juan Valdez. (2020, May 12). Our Icon. Retrieved from Our Brand: https://www.juanvaldezcafe.com/en-us/our-brand/our-Icon/

Keller, K. L. (2005). Gestão estratégica de marcas [Strategic brand management]. São Paulo: Pearson Prentice Hall. 
Kotler, P., Haider, D., \& Rein, I. (1994). Mercadotecnia de localidades [Localities marketing]. México: Diana.

Lazo, L. (2006). Niveles de posicionamiento de marca a nivel internacional [International brand positioning levels]. Contabilidad y Negocios, 1(2), 36-40.

López-Lita, R., \& Benlloch, M. T. (2005). De la marca comercial a la marca territorio [From the commercial brand to the territory brand]. Revista de Pensament $i$ Anàlisi, 5, 87-100.

López-Lita, R., \& Benlloch, M. T. (2006). Necesitamos marcas territorio? [Do we need territory brands?]. Técnica Económica: Administración y Dirección de Empresas, 175, 50-52.

Marchant, I., \& Castro, A. (2017, February 27). El Estado de Social Media en América Latina [The state of social networks in Latin America]. Retrieved from COMSCORE: https://www.comscore.com/lat/Prensa-y-Eventos/Presentaciones-y-librosblancos/2017/El-Estado-de-Social-Media-en-America-Latina

Mercado. (2017, May 28). 40 marcas emergentes del informe Interbrand [40 Breakthrough Brands the Interbrand report]. Retrieved from Management and Marketing: https://mercado.com.ar/management-marketing/40-marcas-emergentes-delinforme-interbrand/

Monerris, A. (2008). Place branding: Planteamientos y enfoques básicos [Place branding: Basic approaches and approaches]. Retrieved from Estrategia de Comunicación: http://goo.gl/ ITeO8

Morales, M. (2010). Debiera ser obligatorio el uso de la marca registrada? [Should the use of the trademark be mandatory?]. Retrieved from Derecho Marcario: http://derechomarcario.blogspot.com/2010/10/debiera-serobligatorio- el-uso-de-la.html

Olins, W. (2005). Making a national brand. In M. J., The New Public Diplomacy. Studies in Diplomacy and International Relations (pp. 169-179). London: Palgrave Macmillan. doi:https://doi.org/10.1057/9780230554931_9

Quintana Lombeida, M., \& Aguilar, J. (2018). Denominación de origen de cacao ecuatoriano: Un aporte de marketing global? [Designation of origin of Ecuadorian cocoa: a global marketing contribution?]. INNOVA Research Journal, 3, 68-76. doi:10.33890/innova.v3.n10.1.2018.825.

Real Academia Española. (2018). Differentiate. Retrieved from Real Academia Española: http://dle.rae.es/?id=DjcR8zI

Schmitz Vaccaro, C. (2012). Distintividad y uso de las marcas comerciales [Distinctiveness and use of commercial brand]. Revista Chilena de Derecho, 39(1), 9-31.

Sherfey, J. (2015, December 16). Juan Valdez and FNC: The Story of Colombian Coffee. Retrieved from Eater: https://www.eater.com/drinks/2015/12/16/10318056/juan-valdez-fnc-colombia-coffee

Stanton, W., Etzel, M., \& Walker, B. (2000). Fundamentos de Marketing (11a ed.) [Marketing fundamentals]. México: Editorial McGraw-Hill.

Trout, J. (2001). Diferenciarse o morir [Differentiate or die]. Madrid: MacGraw-Hill.

van der Lans, I. A., van Ittersum, K., De Cicco, A., \& Loseby, M. (2001). The role of the region of origin and EU certificates of origin in consumer evaluation of food products. European Review of Agricultural Economics, 28(4), 451-477. https://doi.org/10.1093/erae/28.4.451 